Agro-Science Journal of Tropical Agriculture, Food, Environment and Extension Volume 16 Number 2 (May 2017) pp. $31-37$

ISSN 1119-7455

\title{
DETERMINANTS OF ADOPTION LEVEL OF RISK MANAGEMENT STRATEGIES BY FISH FARMERS IN DEGEMA LOCAL GOVERNMENT AREA OF RIVERS STATE, NIGERIA
}

\author{
Ugwuja, V.C. ${ }^{1}$. Dickson-Johnson, P.M ${ }^{1}$. and Familusi, L.C. ${ }^{1}$ \\ Department of Agricultural Economics and Extension, Faculty of Agriculture, University of Port \\ Harcourt, Choba, Rivers State, Nigeria. \\ Corresponding author's email address: vivian.ugwuja@uniport.edu.ng
}

\begin{abstract}
The study examined the socio-economic determinants of level of adoption of risk management strategies by fish farmers in Degema Local Government Area of Rivers State. The study specifically described the socioeconomic characteristics of fish farmers, identified the various sources of risk and determined the socioeconomic factors that influence the level of adoption of risk management strategies. A two-stage sampling technique was used to select sixty-seven (67) fish farmers. Structured questionnaire and interview schedule were used for data collection. Data analysis was done using descriptive statistics and multiple regression. The result showed that majority were young male with an average age of 40 years. The most common sources of risk were the fluctuation in prices of fish feed and fish. The age of farmers, household size, and farming experience were some of the factors that influenced the adoption to risk management strategies. However due to the inadequate extension service activities, farmers were not able to fully utilize the different and essential risk management strategies. Hence, the study recommends that young women should be encouraged to invest in fish farming business. Also, extension agents should be encouraged to disseminate useful information to farmers on essential risk management strategies.
\end{abstract}

Keywords: Risk, Risk Management Strategies, Fish farming, Adoption

\section{INTRODUCTION}

Fish farming is the cultivation of fish species such as catfish and tilapia amongst others. It is a source of food and animal protein for human consumption (Nash, Burbridge \& Volkman, 2005). In Nigeria, fish farming is mostly practiced on small farms (Anyanwu \& Akeredolu, 2005). Fish production is mostly done on plastic containers, concrete, earthen ponds and tarpaulin. The business of fish farming is a lucrative venture. However, fish farming is surrounded by numerous risks resulting from the day to day decision making on farming activities which could be detrimental to the outcome in terms of production and returns (Kahan, 2013). In fish farming, risk could spring up from different farming activities such as breeding, production, marketing, financial and institutional (Kimura, Antón \& LeThi, 2010). Specifically, we have risks that are associated with climate change, fluctuation in prices, imperfect markets, weak rural infrastructure, inadequate credit and insurance scheme for farmers, and poor implementation of government policies. These risk factors affect farmers' income and general wellbeing. Risk is the likelihood that things may not go as planned or hoped for. This is usually in the negative direction. According to Salimonu \& Falusi (2009), risk can be classified as property or personal risk with respect to the incidence of occurrence. The property risk was further divided into natural risk (such as storm, flood, drought, diseases, hail), social risk (such as fire, theft, war, social structure change, embezzlement, technological change) and economic risk (such as changes in prices, unexpected depreciation of assets, adverse terms of trade). Personal risks are risks that arise from human factor such as illness, accident, loss of asset, loss of income. However, to reduce risk effects in the fish farms, one must be willing to reduce the income generated. The reason for this is because there is a direct relationship between risk and farm returns. The more risky the better the venture. The amount of risk to accommodate in a business reflects on the characteristics of the business owner as some owners are risk lovers while some are not. Nevertheless, there are strategies available for fish farmers to manage risks better. Risk management 
Determinants of Adoption Level of Risk Management Strategies by Fish Farmers

by farmers involves choosing among alternatives to reduce the effect of risk on farming activities (Salmonu \& Falusi, 2009). Fish farming is a profitable venture only if the risk management and planning aspects are properly implemented. Therefore, strategies to managing risk which are integral part of a good agri-business practice and would assist in farm decision making.

Considering the economic importance and demand for fish in the country and the world at large, it becomes important to access the risk management strategies used by fish farmers in Degema Local Government Area of Rivers state. Therefore, the general objective of this study was to analyze the level of adoption of risk management strategies among fish farmers in Degema Local Government Area, Rivers State. Specifically, the study described the socioeconomic characteristics of fish farmers, identified the various sources of risk faced by fish farmers, identified the level of adoption of risk management strategies among the fish farmers and determined the socio-economic factors that influence level of adoption of risk management strategies among the fish farmers

\section{RESEARCH METHODOLOGY}

The study was carried out inDegema Local Government Area (LGA)of Rivers state, Nigeria. It comprises of eleven villages/towns namely Degema town, Tombia, Bokana, Old Bokana, Bille, Ke town, Usokun, Obuama, Bukuma, Consulale and Elem Ama. Degema LGA is a fish producing area because of the abundance of water bodies in the region. Thepopulation of the study comprised all the fish farmers in the study area. Two stage sampling technique was used to select the sample size. In the first stage, purposive sampling was used to select two communities (Degema and Usokun.). Purposive selection was done because of large number of fish farmers in these communities relative to other communities. In the second stage snow ball sampling technique was used to select thirty-five(35) fish farmers from each community. This gives a total of seventy (70) fish farmers. However, out of the 70 sampled farmers, only sixty-seven (67) copies of questionnaires were retrieved. Thus, data analysis was based on these 67 respondents. Primary data were collected using a structured questionnaire. Descriptive statistics such as mean and percentages and the multiple regression model were used to achieve the objectives of thestudy. The implicit form of the multiple regression model is shown in equation (1) below:

$Y=f\left(X_{1}, X_{2}, X_{3}, X_{4}, X_{5}, X_{6}, X_{7}, X_{8}, X_{9}, X_{10}\right)+e \ldots \ldots .(1)$ where $\mathrm{Y}$ represents the level of adoption of risk management strategies and was derived as U/V $\mathrm{X}$ $100, \mathrm{U}$ represent the number of risk management strategies adopted by a farmer, $\mathrm{V}$ represents the total number of risk management strategies, $X_{1}$ represents the sex of the farmer ( $1=$ female, 0 otherwise), $\mathrm{X}_{2}$ represents theage of the farmer (years), $\mathrm{X}_{3}$ representsthe marital status $(1=$ married, 0 otherwise), $\mathrm{X}_{4}$ represents the level of education (years) ( $1=$ formal education, 0 otherwise) , $\mathrm{X}_{5}$ represents the extension contact (1=yes, 0 otherwise), $\quad \mathrm{X}_{6} \quad$ represents household size, $\mathrm{X}_{7}$ represents farming status (1=fulltime, 0 otherwise), $X_{8}$ represents cooperative membership (1=yes, 0 otherwise), $X_{9}$ represents level of farming experience (years), $X_{10}$ represents the number of fish stocked and e represent the error term. The linear, exponential, semi-log and double log functional forms of the equation were tried out, however the equation that best fit the regression line with respect to the highest $\mathrm{R}^{2}$ value was used.

\section{RESULTS AND DISCUSSIONS \\ Distribution of socio-economic characteristics of fish farmers in the study area.}

The results presented in Table 1 showed that majority $(80.6 \%)$ of the fish farmers were male while $19.4 \%$ were female. This is an indication that fish farming in the study area was dominated by men. Results showed that majority $(62.8 \%)$ of the fish farmers were within the age bracket of 20-40 years with a mean age of 40 years. This indicates that most of the fish farmers were young and therefore still have the strength to run the business. This is in line with Henri-Ukoha (2012) who noted that fish farming had considerable involvement of youths. It was also observed that majority of the respondents were married $(55.2 \%)$. This is in consonance with Oladeja, Adedoyin and Adedokun (2008) who observed that most fish farmers were married which implied that marriage confers individual with some level of responsibility and commitment. The result further showed that majority $(67.2 \%)$ of the fish farmers had household size ranging from 1-5 persons with a mean household size of 5 . The size of the family has a direct influence on the expenditure and income patterns of the family as such fish farming is a labour intensive activity hence large households positively influence fish farming (Pandey \& Upadha-yah, 2012). 
Ugwuja, V.C. Dickson-Johnson, P.M. and Familusi, L.C

Table 1:Distribution of socio-economic characteristics of fish farmers in the study area

\begin{tabular}{|c|c|c|c|}
\hline Variable & $\begin{array}{l}\text { Freque } \\
\text { ncy }\end{array}$ & $\begin{array}{l}\text { Percentage } \\
(\%)\end{array}$ & $\begin{array}{l}\text { Mea } \\
\mathrm{n}\end{array}$ \\
\hline & (67) & & \\
\hline \multicolumn{4}{|l|}{ Age } \\
\hline $20-40$ & 42 & 62.8 & \\
\hline $41-60$ & 20 & 29.8 & 40 \\
\hline 61 and above & 5 & 7.4 & \\
\hline \multicolumn{4}{|l|}{ Sex : } \\
\hline Male & 54 & 80.6 & \\
\hline Female & 13 & 19.4 & \\
\hline \multicolumn{4}{|l|}{ Maritalstatus } \\
\hline Single & 30 & 44.8 & \\
\hline \multirow{2}{*}{\multicolumn{4}{|c|}{ Household size }} \\
\hline & & & \\
\hline $1-5$ & 45 & 67.2 & \\
\hline $6-10$ & 19 & 28.4 & 5 \\
\hline 11 and above & 3 & 4.5 & \\
\hline Educationalstatus & & & 13 \\
\hline Non-formal education & 0 & 0 & \\
\hline Primary education & 4 & 6.0 & 13 \\
\hline Secondary education & 33 & 49.3 & \\
\hline Tertiary education & 30 & 44.7 & \\
\hline \multicolumn{4}{|l|}{ Farmingstatus } \\
\hline Full time & 36 & 53.7 & \\
\hline Part time & 31 & 46.3 & \\
\hline \multicolumn{4}{|l|}{ Farming experience } \\
\hline $1-5$ & 46 & 68.6 & \\
\hline $6-10$ & 20 & 29.9 & 5 \\
\hline $11-15$ & 1 & 1.5 & \\
\hline \multicolumn{4}{|l|}{ Number of fish stocked } \\
\hline Below 1,000 & 30 & 44.8 & \\
\hline $1,000-5,000$ & 29 & 43.2 & 2518 \\
\hline $5,001-10,000$ & 8 & 12.0 & \\
\hline Extensionservice visit & & & 7 \\
\hline Yes & 25 & 37.3 & \\
\hline No & 42 & 62.7 & \\
\hline \multicolumn{4}{|l|}{ Belong to cooperative } \\
\hline Yes & 27 & 40.3 & \\
\hline No & 40 & 59.7 & \\
\hline
\end{tabular}

Analysis on educational status showed that $49.3 \%$ had secondary education while the mean for number of years spent in school was 13 years. Education plays an important role in farm decision making, helps the farmer to gain skills, adopt new technologies in fish farming and business transactions. This is in agreement with the findings of Alene, Pourith \& Hassan (2000) who observed that level of education influences farmer's adoption rate. Yarhere (2004) noted that fish farming is dominated by educated class and mostly by those armed with high level of education, this is because fish farming requires a lot of technical and scientific knowledge to be successfully undertaken. Majority $(53.7 \%)$ of the respondents were full time farmers while $(46.3 \%)$ were part time. This indicates that farmers involved in fish farming in the study area mostly do not have other profession and this gives more concentration while less fish farmers do have other profession. Agricultural extension service is an avenue for fish famers whether literate or illiterate to be educated on simple innovations of improving their life style through their farming operation. This type of education improves their knowledge level in the operations. The result showed that majority $(62.7 \%)$ of the respondents did not have access to extension service while $37.3 \%$ had access to extension service. The result further showed that majority $(68.7 \%)$ had between $1-5$ years of farming experience, while the mean years of farming experience was 5. This indicates that most of the fish farmers have acquired fish farming experience that is good enough to increase their productivity and knowledge. This is in accordance with Yahere (2004) who stated that farmers with longer years of experience have good skills, better approaches to fish farming business and were able to forecast market situation on which they sell their products at higher prices than those with less years of experience. aMembership of cooperative is an advantage for farmers to get information to improve their operations. The results show that majority $(59.7 \%)$ of the fish farmers in the study area did not belong to any cooperative. While $40.3 \%$ belong to cooperatives. Akinbile (1998) stated that cooperative society involves a social participation that helps farmers to pool their resources, to have access to fisheries inputs and to have insight in their funding issues, membership of the cooperative society is therefore a factor that influences the adoption of improve fisheries technologies and poverty alleviation and the group ensures that members derives benefits from the groups such that they would not have derived individually, if they were acting alone. The result showed that $44.8 \%$ stocked fish ranging from 1000- 5000, with a mean size of 2518 which indicates that the fish farmers in the study area were operating in small scale production. 
Determinants of Adoption Level of Risk Management Strategies by Fish Farmers

\section{Distribution of various sources of risk faced by fish farmers in the study area.}

The result presented in Table 2 showed that majority $(50.7 \%)$ of fish farmers in the study area were faced with disease outbreak in their fish farming operations while $(49.3 \%)$ were not affected. Disease outbreak causes wide variation in yield. This is in agreement with the finding of Salimonu and Falusi (2009) who noted that disease outbreak affect the activities of fish farmers and reduce their yield. The result further showed that $55.2 \%$ of the respondents did not experience bird attack while $44.8 \%$ were experiencing bird attack on their fish farming activities. Most of the respondent $(80.6 \%)$ did not encounter flood while $19.4 \%$ encountered flood. The result further showed that all $(100 \%)$ the fish farmers in the study area did not experience drought. This implies that drought is not a risk faced by fish farmers in the study area. Analysis of the result also showed that $86.6 \%$ of fish farmers were not affected by bush burning in their fish farming activities while only $13.4 \%$ were affected. This indicated that the occurrence of bush burning was not severe in the study area. The risk of price fluctuation affects fish production. The result showed that majority $(65.7 \%)$ of fish farmers in the study area experienced fluctuation in price of fish. This conforms with the findings of Salimonu and Falusi (2009) who indicated that market failure which affects agricultural produce also hinders the production of fish. This indicated that fluctuation in fish price is a risk faced by the fish farmers. This is in consonance with the findings of Alan et al., (2004) who stated that low level of fish production are associated with high price variation. The result further showed that $73.1 \%$ of fish farmers in the study area were faced with the risk of fluctuation in the price of feed. This is an indication that price fluctuation in the market is a risk that hinders the production of fish. Most of the respondents $(61.2 \%)$ were not faced by the risk of illness while $(38.8 \%)$ faced the risk of illness. This is an indication that risk due to illness is not high in the study area. Loss of property can occur as a result of theft. The result showed that $47.8 \%$ of fish farmers were affected with risk due to theft while $52.2 \%$ were not affected by theft. This showed that theft in the study area is not a major risk that affects the fish production activities in the study area. The result also showed that $56.9 \%$ of the fish farmers were not affected by the risk due to pond leakage while $43.2 \%$ were affected by risk due to pond leakage.
Table 2: Distribution of the various sources of risk faced by fish farmers in the study area

\begin{tabular}{|c|c|c|c|}
\hline Sourceofrisk & Freq & Percentage & Rank \\
\hline Disease : Yes & 34 & 50.8 & $6^{\text {th }}$ \\
\hline No & 33 & 49.3 & \\
\hline Bird attack : Yes & 30 & 44.8 & $8^{\text {th }}$ \\
\hline No & 37 & 55.2 & \\
\hline Flood : Yes & 13 & 19.4 & $12^{\text {th }}$ \\
\hline No & 54 & 80.6 & \\
\hline Drought : Yes & 0 & 0 & $16^{\text {th }}$ \\
\hline No & 67 & 100 & \\
\hline Bush burning : Yes & 9 & 13.4 & $14^{\text {th }}$ \\
\hline No & 58 & 86.6 & \\
\hline Price of fish fluctuating: Yes & 44 & 65.7 & $2^{\text {nd }}$ \\
\hline No & 23 & 34.3 & \\
\hline $\begin{array}{l}\text { Price of feed fluctuating in the } \\
\text { market: Yes }\end{array}$ & 49 & 73.1 & $1^{\mathrm{st}}$ \\
\hline No & 18 & 26.9 & \\
\hline Illness : Yes & 26 & 38.8 & $10^{\text {th }}$ \\
\hline No & 41 & 61.2 & \\
\hline Theft : Yes & 32 & 47.8 & $7^{\text {th }}$ \\
\hline No & 35 & 52.2 & \\
\hline Pond leakage : Yes & 29 & 43.3 & $9^{\text {th }}$ \\
\hline No & 38 & 56.7 & \\
\hline Oil spillage : Yes & 2 & 3 & $15^{\text {th }}$ \\
\hline No & 65 & 97 & \\
\hline War (communal clash) : Yes & 0 & 0 & $16^{\text {th }}$ \\
\hline No & 67 & 100 & \\
\hline Death : Yes & 42 & 62.7 & $4^{\text {th }}$ \\
\hline No & 25 & 37.3 & \\
\hline Increase in interest for loan : Yes & 16 & 23.9 & $11^{\text {th }}$ \\
\hline No & 51 & 76.1 & \\
\hline High cost of labour: Yes & 43 & 64.2 & $3^{\text {rd }}$ \\
\hline No & 24 & 35.8 & \\
\hline $\begin{array}{l}\text { Owner of land is threatening to take } \\
\text { back his land: Yes }\end{array}$ & 10 & 14.9 & $13^{\text {th }}$ \\
\hline No & 57 & 85.1 & \\
\hline Unavailability of loan : Yes & 40 & 59.7 & $5^{\text {th }}$ \\
\hline No & 27 & & 40.3 \\
\hline
\end{tabular}

Source: Field survey, 2015

Table 3: Adoption of risk management strategies among fish farmers in the study area

\begin{tabular}{|c|c|c|c|}
\hline Risk management strategies & Frequency & Percentage & Rank \\
\hline Insurance & & & $5^{\text {th }}$ \\
\hline Yes & 5 & 7.5 & \\
\hline No & 62 & 92.5 & \\
\hline $\begin{array}{l}\text { Diversification to non-farm } \\
\text { income generating activity }\end{array}$ & & & \\
\hline Yes & 28 & 41.8 & $2^{\text {nd }}$ \\
\hline No & 39 & 58.2 & \\
\hline Sellingofassets & & & $4^{\text {th }}$ \\
\hline Yes & 18 & 26.9 & \\
\hline No & 49 & 73.1 & \\
\hline $\begin{array}{l}\text { Borrowing from } \\
\text { neighbour/family }\end{array}$ & & & $3^{\text {rd }}$ \\
\hline Yes & 24 & 35.8 & \\
\hline No & 43 & 64.2 & \\
\hline Mixed farming & & & $1 \mathrm{st}$ \\
\hline Yes & 38 & 56.7 & \\
\hline No & 29 & 43.3 & \\
\hline
\end{tabular}

Source: Field survey, 2015 
Ugwuja, V.C. Dickson-Johnson, P.M. and Familusi, L.C

Table 4: Regression results of level of adoption of risk management strategies

\begin{tabular}{lllll}
\hline Variables & linear & semi log & Exponential & double log \\
\hline Constant & $13.928(1.258)$ & $-121.276(-4.879)$ & $-1.432(-1.680)$ & $2.432(5.617)$ \\
Sex $\left(\mathrm{X}_{1}\right)$ & $0.960(0.454)$ & $1.126(0.409)$ & $0.053(0.654)$ & $0.042(0.380)$ \\
Age $\left(\mathrm{X}_{2}\right)$ & $-0.133(-1.012)$ & $3.270(0.596)$ & $-0.005(-1.973)$ & $-0.089(-2.402)^{* *}$ \\
Marital status $\left(\mathrm{X}_{3}\right)$ & $3.294(2.174)^{* *}$ & $4.378(1.609)$ & $0.213(1.960)^{* *}$ & $0.371(3.700)^{* * *}$ \\
Level of education $\left(\mathrm{X}_{4}\right)$ & $1.092(0.678)$ & $1.097(0.371)$ & $0.069(1.108)$ & $0.144(1.206)$ \\
Extension Contact $\left(\mathrm{X}_{5}\right)$ & $0.302(0.438)$ & $0.533(0.334)$ & $0.003(0.126)$ & $0.034(0.064)$ \\
Household size $\left(\mathrm{X}_{6}\right)$ & $0.347(5.773)^{* * *}$ & $0.419(1.899)^{*}$ & $0.019(2.107)^{* *}$ & $0.051(6.603)^{* * *}$ \\
Farming status $\left(\mathrm{X}_{7}\right)$ & $-7.850(-3.163)^{* * *}$ & $-3.787(-1.094)$ & $-0.311(-3.236)^{* * *}$ & $-0.148(-2.061)^{* *}$ \\
oop. member $\left(\mathrm{X}_{8}\right)$ & $-0.022(-0.480)$ & $-0.331(-0.177)$ & $-0.015(-.230)$ & $-0.559(-0.433)$ \\
Farming experience $\left(\mathrm{X}_{9}\right)$ & $0.845(3.419)^{* * *}$ & $3.408(2.109)^{* *}$ & $0.036(6.019)^{* * *}$ & $0.222(5.402)^{* * *}$ \\
No. of fish stocked $\left(\mathrm{X}_{10}\right)$ & $5.628(0.445)$ & $11.774(1.056)$ & $1.498(1.436)$ & $0.346(1.595)$ \\
$\mathrm{R}^{2}$ & 0.690 & 0.626 & 0.674 & 0.751 \\
F-value & $19.368^{* * *}$ & $14.888^{* * *}$ & $18.863 * * *$ & $26.818^{* * *}$ \\
\hline Source: Data analysis $(2015)^{* * * *}$ Significant at & $1 \%$ level, ** Significant at 5\% level, *Significant at $10 \%$ level ,Values in \\
parenthesis are the t- values. & & &
\end{tabular}

This indicated that risk due to pond leakage in the study area were fairly high. The result further showed that $97.3 \%$ of the respondents did not encounter oil spillage while only $3 \%$ of the respondents encountered oil spillage in their fish farming activities. Hence there was no much occurrence of oil spillage in the study area. The result showed that all $(100 \%)$ of the fish farmers in the study area did not experience war. Therefore war is not a risk that hinder the production of fish production. Death of fishes can be as a result of disease outbreak which leads to wide variation in yield hence the result showed that $62.7 \%$ of the fish farmers were faced with the risk due to death while $37.3 \%$ were not faced with death of fishes. This implies that death of fishes is a severe risk faced by the fish farmers. Most $(76.1 \%)$ of the respondents in the study area did not encounter increase in interest for loan this may be as a result of lack of credit facilities while only $23.9 \%$ of the fish farmers encountered increase in interest for loan. The result showed that majority $(64.2 \%)$ of fish farmers experienced high cost of labor in their fish farming activities. This implies that high cost of labor was severe and it could be as a result of the migration of youth to urban centers in search of white collar jobs. Owner of land threatening to take back his land is not a severe risk that hinders the production of fish in the study area, this may due to availability of land through inheritance or by lease. The result showed that $85.1 \%$ of the fish farmers did not encounter the risk due to owner of land threatening to take back his land while only $(14.9 \%)$ encountered the risk due to owner of land threatening to take back his land. Credit plays important role in the production of fish and production as a whole. Majority of the fish farmers $(59.7 \%)$ experience unavailability of loan while $40.3 \%$ of fish farmers did not experience unavailability of loan. This may be due to lack of credit facilities from banks, government and non- governmental organizations and the high interest rate involved in loan access.

\section{Adoption of risk management strategies among fish farmers in the study area.}

The results presented on Table 3 showed that majority $(92.5 \%)$ of the fish farmers in the study area did not adopt insurance as a risk management strategy while only $7.5 \%$ of fish farmers adopted insurance as a risk management strategy. This indicated that the fish farmers in the study area have a low adoption of insurance as a risk management strategy. This does not conform with the findings of Drollette (2009) who pointed that insurance are effective risk management tools mostly used by farmers. The result further showed that only $41.8 \%$ of fish farmers adopted diversification to non- farm income generating activity. This implies that there is a low level of adoption of diversification in the study area. The result also showed that $73.1 \%$ of fish farmers did not employ selling of asset as a risk management strategy. Analysis from the result also showed that majority $(64.2 \%)$ of fish farmers in the study area did not adopt borrowing from neighbors and family as a risk management strategy. Result further showed that majority $(56.7 \%)$ of the fish farmers adopted mixed farming as a risk management strategy.

Determinants of level of adoption of risk management strategies by fish farmers in Degema Local government Area of Rivers State. From Table 4, the double log form was chosen as the lead equation based on the highest value of $\mathrm{R}^{2}$ (75\%) and conformity to theoretical expectations of the regression coefficients. The result showed that household size and farming experience had positive coefficients, meaning that the more of these variables the more the increase in level of adoption of risk management strategies. This was in-line 
Determinants of Adoption Level of Risk Management Strategies by Fish Farmers

with the findings of Oladojaet al (2008) who reported that household size and farming experience were positively important to fishing. Age $\left(\mathrm{X}_{2}\right)$ is significant at $5 \%$ and related negatively to level of adoption of risk management strategies. This implies that being a younger farmer increases the probability of adopting more risk management strategies. The negative effects of age may be due to younger farmers having more strength to adopt to different risk management strategies. Marital status $\left(\mathrm{X}_{3}\right)$ was significant at $5 \%$ and has positive coefficient. This implies that being married increases the level of adoption of risk management strategies and could be saddled on the quest to meet family responsibility. Household size $\left(\mathrm{X}_{6}\right)$ was significant at $1 \%$ and it related positively to level of adoption of risk management strategies. This implies that larger households would have more labor input which will enhance adoption of more risk management strategies. This findings agree with the work of Euphraise (2009) who reported that large farm household tend to adopt more of risk management strategies. Farming status $\left(\mathrm{X}_{7}\right)$ was significant at $1 \%$ and has negative coefficient. This shows that being a full time agro-entrepreneur reduces the chances of adopting more of risk management strategies. This may be due to parttime agro-entrepreneurs getting income from other sources and increasing their chances of having more resources that will enable them to adopt more risk management strategies. The coefficient of years of farming experience (X9) is positive and statistically significant at $1 \%$. The positive effects of farming experience on level of adoption of risk management strategies may be due to the fact that fish farmers are becoming more knowledgeable in business practices which can increase their knowledge of importance of using different strategies to avert risk. This result disagrees with the findings of Euphraise (2009) who reported that farming experience decreases the possibility of using risk management strategies.

\section{CONCLUSION AND RECOMMENDATIONS}

Fish farming serves as a good source of livelihood to farmers in Nigeria. Farmers' encountered risk as fluctuation of the prices of fish feed and fish in the market, high cost of labor, disease and death of fish and unavailability of loan. However, through the use of some risk management strategies, farmers were able to manage risk to a certain level but due to inadequate extension visits, insufficient financial assistance and not belonging to cooperative society, farmers were not able to adopt intensively to risk management strategies. Farmers adopted some strategies such as mixed farming, diversification, use of local feeds, use of family labour and borrowing from friends and family. Furthermore, risk management strategies adopted by farmers were influenced positively by being married and having a large household size that can constitute farm labor given the fact that fish farming is labor intensive.

Therefore, the study recommends that loans should be made available so that fish farmers can increase the adoption to risk management strategies. Fish farmers should be encouraged to be members of agricultural cooperatives in order to be better informed. Also, agricultural extension service should be made available in order to train and equip the fish farmers on new innovation and risk management skills. Lastly, women should be encouraged to engage in fish farming activities as a source of livelihood.

\section{REFERENCES}

Akinbile, L. A. (1998). Group formulation and group dynamics paper presented and NAERLS Workshop on Extension Commission Techniques More plantation Ibadan p. 11.

Alan, M., Craig D., James, P., Micheal, B., \& Cole E., (2004). Risk Management for Farmers. Staff paper submitted to the Department of Agricultural Economics and Extension. Prudue University, West Lafeyetle, Indiana.

Alene, A. D., Pourith, D.,\&Hassen, R. M. (2000). Determinants of adoption and intensity of useof improved rice varieties in the central highland of Ethiopia: A fobal analysis Agerkon South, African Journal of Agriculture Economics 39(4): 633 643.

Anyanwu, D.,\&Akeredolu, B, (2005).Urban Aquaculture in Nigeria World Aquaculture Society.Annual report www.org/meeting/abstract data.

Drollette S. A. (2009). Managing Production Risk in Agriculture department of applied economics Utah State university. publication issued in cooperative Extension workshop, act of May and June 1994, in cooperation with U.S Department of Agriculture.

Euphrasie B, K (2009). Risk, risk aversion and choice of risk management strategies by cocoa farmers in western cote d'ivoire, University of Cocody AERC Collaborative PhD Programme

Henri-Ukoha, A. (2012). Profitable fish for farming toward the attainment of the Millennium Development Goals (MDGs).A case study off catfish farmers in Aba agricultural zone of Abia State, Nigeria.ARPN Journal of Science and technology, 2(7):2225 - 7217.

Kahan, D. (2013). Farm management extension guide. Managing risk in farming. Food and Agriculture Organization of the United Nations, Rome.

Kimura, S., Antón, J., \& LeThi, C. (2010). Farm level analysis of risk and risk management strategies and policies: cross country analysis. Paris: OECD 
Ugwuja, V.C. Dickson-Johnson, P.M. and Familusi, L.C

Food, Agriculture and Fisheries Papers, No. 26, OECD Publishing. Retrieved from http://dx.doi.org/10.1787/5kmd6b5rl5kd-en

Nash, C. E., Burbridge,P. R.,\&Volkman, J. K. (2005), Guidelines for ecological risk assessment of marine fish aquaculture U.S Department Commer, NOAA Tech. Meno. MNFS-NWFSC 71.

Oladoja, M.A., Adedoyin, S.E.,\&Adedokun .O.A (2008). Training needs of Fisheries Folks on Fishing Technology. Journal of Food Agricultural and Environment Science and Technology.Vol.6. No NFL Publisher, Helsinki,
Pandey D, K.,\&Upadhayay, A. D. (2012) socioeconomic profile of fish farmers of an adopted model aquaculture village: Kulubari, West Tripura. Indian research journal of extension education, special issue 1:(2).

Salimonu, K.,\& Falusi, A. O. (2009). Sources of risk and management strategies among food crop farmers in Osun State, Nigeria. African Journal of Food Agriculture Nutrition and Development, 9(7): 1591-1605.

Yarhere, M. (2004) A study of men's participation to food security and poverty alleviation in Lagos and Ogun States. In. fiso-N cont. Proceedings P. A. Araoye (ed) pp. 167-1778. 